\title{
THE INFLUENCE OF THINKING STYLES AND MATHEMATICAL BELIEFS ON THE ELEMENTARY MATHEMATICS TEACHER'S COMMUNICATION ABILITY
}

\author{
Alifa Sabrina ${ }^{1}$, Suyono Suyono ${ }^{2}$, Wardani Rahayu ${ }^{3}$ \\ 1,2,3 IKIFA Pharmacy Academy, East Jakarta, Indonesia \\ alifasabrina99@gmail.com
}

\begin{abstract}
The aim of the research was to determine the influence of thinking styles and mathematical beliefs of Elementary Mathematics Teacher according to their mathematics communication ability. The participants were 60 elementary teachers in UPBJJ-UT (Terbuka University) Jakarta. They were chosen as a sample with simple random sampling technique, where the test was held in June 14, 2015. The Multiple Linier Regression was used to analyzed the data, where the instruments consist mathematics communication, thinking styles and mathematical beliefs. Based on the value of R square applied in the SPSS, showed that there is 0.457 or $45.7 \%$ the influence of mathematical beliefs and thinking styles according to the mathematics communication in students in Elementary Teacher Studies program in UPBJJ-UT Jakarta.
\end{abstract}

Keywords: Mathematics Communication, Thinking Styles, Mathematical Beliefs, Elementary Teachers, Multiple Linier Regression.

The National Council Teachers of Mathematics (NCTM) in its rules and regulations stresses the role mathematics communication and technological advancements as well as students' productions of mathematical representations for all grades when learning mathematics (NCTM, 2000). This is in line with the recent Order from Department of Education (Permendikbud) No. 64 in 2013, which states that one of the competency of learning mathematics in high school is to communicate the idea of mathematics clearly (Department of Education, 2013). Communicating skills is the ability of students to express their idea and concepts of mathematics coherently, in written and oral communication. In addition, The Mathematics Association of America (MAA) states that developing students' mathematics communication is by written and oral communication (Schoenfeld, 1990). It is because elaborated communication through written and oral form show clarity of understanding the idea and concepts in mathematics. The statements by MAA was represented in Maier's, Rahman, Kuinisala, and Braga's studies (Maier, 2000)(Rahman, 2012)(Kuinisala, 2005)(Braga, 2003), their studies show that writing offers a chance for students to create their own texts of mathematical concepts. Long time ago before the presents research, Baroody and Gardner already predicted that mathematics communication ability together with the ability to solve problems scientifically as is the most valued skills in educational practices globally presently (Baroody, 1993)(Gardner, 1983). Additionally, the study done by Lomibao et al shows that mathematical communication is effective in improving students' achievement, conceptual understanding and reducing the anxiety (Lomibao, 2016). The previous studies show how important mathematical communication is in developing the students' ability of mathematics communication especially since in the elementary school.

Developing the students' mathematics communication through written and oral depends on their thinking styles and, how they use their cognitive ability. Differences in processing the 
information based on the habit or preferences that characterizes a person's thought is called thinking styles. Sunbul define a thinking style as an approaches and leanings based on the mental processes, which is related to events, phenomenon, and various problems (Sünbül, 2004). It is also related to the environment and could be changed according to time and culture (Zabukovec and Kobal-Grum, 2004). The study done by Uygun and Kunt shows the positive results according to positive thinking styles and the learning outcome (Uygun and Kunt, 2014). Another aspect related with the mathematics learning outcome is students' beliefs. According to Mandler (Mandler, 1989) and McLeod (McLeod, 1989), students' beliefs play an important role in the construction of their emotion and attitudes in mathematics learning based on their experiences in the classroom. Also, the studies done by some researchers showed that the learning outcome of students are strongly related to their beliefs and attitude towards mathematics (Schoenfeld, 1992)(Thompson, 1992)(Furinghetti and Pehkonen, 2000)(Leder, Pehkonen and Torner, 2002). The students' beliefs together with the positive thinking styles in mathematics learning lead to positive learning outcome. Those studies leads our interest to find out if there is any influence of mathematical beliefs and thinking styles of teacher through teacher' mathematics communication ability. It is because learning mathematics these days still adopt the concept, where all the knowledge are given directly from teacher to students. It means that the quality of teachers is the most important factor in improving the quality of education (Amsberg, 2010). In addition, the teachers' beliefs and values about teaching and learning affect their teaching practices (Deborah, 2001) and enhancing students' creativity (Ayele, 2016). The study therefore aims to examine the influence of mathematical beliefs and thinking style on the elementary mathematics teachers' communication ability.

\section{METHOD}

\section{Research Design}

The type of design was used in this research is Survey, where sample from the population were used to describe the characteristics, attitudes, behaviors or opinion of the population. Independent variable is mathematics communication $(\mathrm{Y})$ and thinking styles and mathematical belief as a dependent variables $(\mathrm{X})$, as shown.

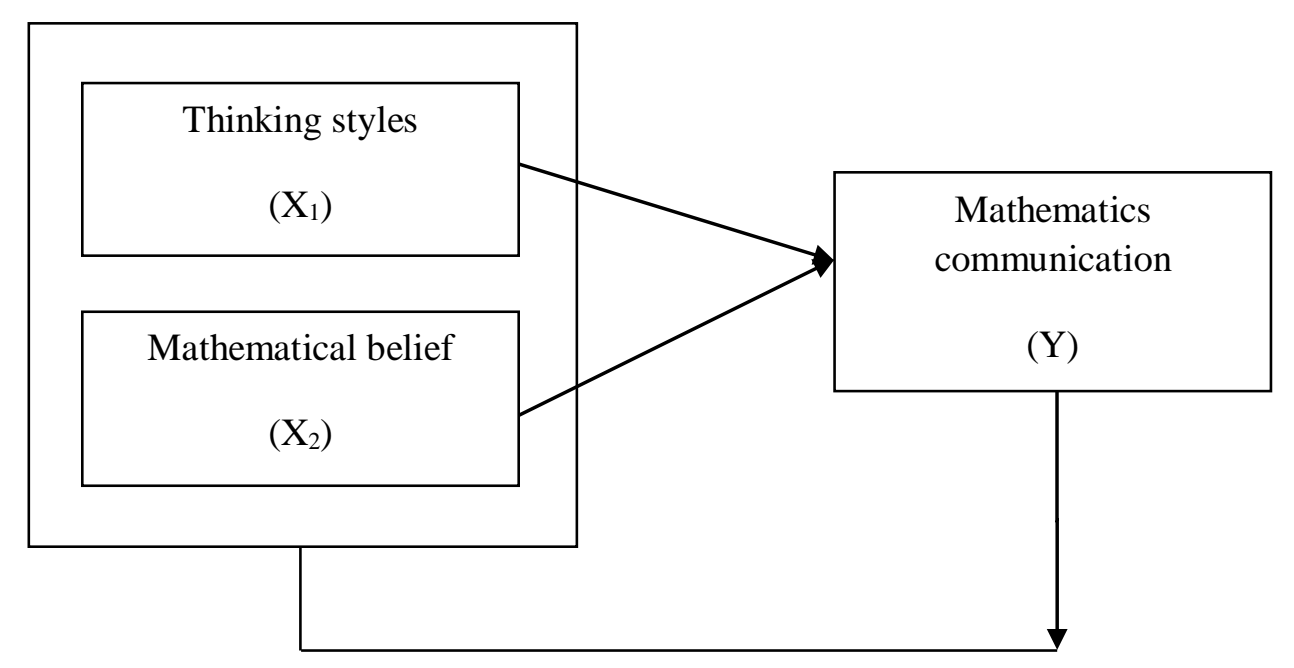




\section{Research Participants}

The participants were 60 elementary teachers in UPBJJ-UT (Terbuka University) Jakarta. They were generally students in Elementary Teacher Studies program in UPBJJ-UT Jakarta. The participants were chosen as a sample with simple random sampling technique, where the test was held in June 14, 2015.

\section{Instruments}

Instruments for this research consist mathematics communications, mathematical beliefs and thinking styles as explained.

\section{Mathematics Communication}

Mathematics instruments in multiple choice was used to measure the mathematics communication ability with the indicators as follow. Participants are able to express a figure, diagram, or a real situation into mathematical language, symbol, idea, or model; participants are able to explain or clarify mathematical ideas, situation, or relation in daily language orally or written; participants are able to express daily situation in mathematics language and symbols; participants are able to read, to clarify, and to examine mathematical presentation meaningfully; and participants are able to formulate definitions and generalizations in mathematics.

\section{Mathematical Belief}

The indicators of mathematical beliefs for this study are successful in learning mathematics; teacher factors; the importance of knowing mathematics; the application of mathematics in daily life and other field; mathematics as a number; and mathematics as a calculating process and problem solving. The instruments were collected by Likert scale, where 4 points for strongly agree statement; 3 points for agree statement; 2 points for slightly agree statement; 1 point for disagree statement; and strongly disagree have 0 point.

\section{Thinking Styles}

In this study, thinking styles of the participants was classified into two dimensions, which are lateral and vertical. This classification is based on the research of Sharma and Neetu in 2011 (Sharma and Neetu, 2011). Ordinal scale was used to measure the thinking styles of the participants, where 2 were given to a points for teacher who tend to think laterally (right brain is dominant), and 1 point for the one who tend to think vertical (left brain is dominant). This assessment is based on the explanation of De Bono about thinking styles (De Bono, 1970). The indicators of thinking styles for this study are freedom of thought in mathematics; solve the problem in every way; classification of objects based on a particular relationship pattern; responding to a condition; and expressing the opinion.

\section{Preliminary Data Analysis}

\section{Validity Test}

Validity test consist content and empiric validity. The content validity is a test to measure how well a test is measuring a quality of the content related to syllabus or Garis-garis Besar Program Pengajaran (GBPP). Ten panelists who is an expert in mathematics and language has done it. Widely 
used method of measuring content validity was developed by C. H. Lawshe (Naga, 2012), which is given by

$$
C V R=\frac{M_{P}-\frac{M}{2}}{\frac{M}{2}}=\frac{2 M_{P}}{M}-1,
$$

where $C V R$ is a content validity ratio, $M_{P}$ is a number of panelist indicating "essential" and $M$ is total number of panelist. The criteria are, if $C V R \geq 0$ means "essential" or instrument were accepted and if $C V R<0$ then instruments were rejected.

After the content validity, the empiric validity was done by testing the instruments with 100 elementary teachers in some school in Jakarta. The Pearson Correlation Coefficient (Arikunto, 2009) as denoted by $r$ was used to measure the strength of a linear association between two variables. The two variables are score of each instrument $(X)$ and total score all instruments of one teacher $(Y)$. The Pearson Correlation Coefficient can be written as

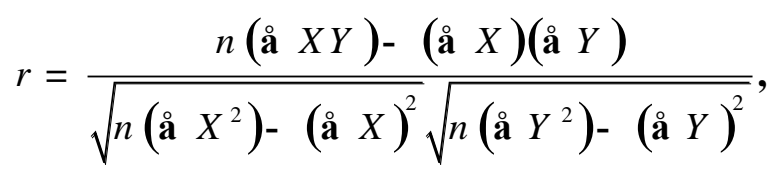

where $n$ is a number of participant. The level of significant is 0,05 , then the value of $r$ from calculation $\left(r_{c a l}\right)$ was comparing with the value of $r$ from the critical values of Pearson Product Moment Correlation Coefficient $\left(r_{c r i}\right)$. If $r_{c a l}>r_{c r i}$ then the instrument is valid to use, and if $r_{c a l}<r_{c r i}$ then the instrument is rejected to use.

\section{Reliability test}

Reliability is synonymous with the consistency of the instrument. Then, the goal of reliability test is to find out the consistency of the instruments before use it to the participants. The Cronbach's Alpha (Arikunto, 2009), which denoted by $a$ is a measure used to assess the reliability of instrument, it was given by

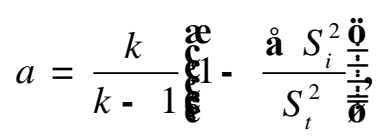

where $k$ is total number of instruments, $\mathbf{a} S_{i}^{2}$ is total number of variants for every instruments and $S_{t}^{2}$ is total variants. The results were interpreted and analyzed using the Cronbach's Alpha, as shown in Table 1 (Hair etc, 2011). 
Table 1.

Rule of Thumb About Cronbach's Alpha Coefficient Size

\begin{tabular}{|c|c|}
\hline Cronbach's Alpha Coefficient Range & Strength of Association \\
\hline$<0.6$ & Poor \\
\hline 0.6 to $<0.7$ & Moderate \\
\hline 0.7 to $<0.8$ & Good \\
\hline 0.8 to $<0.9$ & Very Good \\
\hline$>0.9$ & Excellent \\
\hline
\end{tabular}

Testing criteria are, if the value of $a$ from the calculation $a_{c a l}>a_{c r i}$ the value of $a$ from the Pearson Product Moment Correlation Coefficient, then the instruments are reliable to use, and vice versa. The validity and reliability test for every variable are shown in Table 2.

Table 2.

Preliminary Data Analysis

\begin{tabular}{|c|c|c|c|c|}
\hline \multicolumn{2}{|c|}{$\begin{array}{l}\text { Preliminary } \\
\text { Data Analysis }\end{array}$} & $\begin{array}{l}\text { Mathematics } \\
\text { communication }\end{array}$ & Mathematical beliefs & Thinking styles \\
\hline \multirow[b]{2}{*}{ 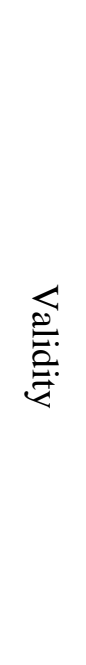 } & 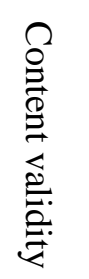 & $\begin{array}{l}20 \text { instruments are proper } \\
\text { to use, because they have } \\
\text { the value of } C V R>0 \text {. }\end{array}$ & $\begin{array}{l}28 \text { instruments are } \\
\text { proper to use, because } \\
\text { they have the value of } \\
C V R>0 \text {. }\end{array}$ & $\begin{array}{l}20 \text { instruments are } \\
\text { proper to use, because } \\
\text { they have the value of } \\
C V R>0 \text {. }\end{array}$ \\
\hline & 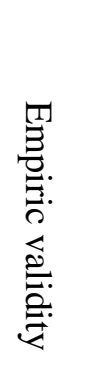 & $\begin{array}{l}14 \text { instruments are valid to } \\
\text { use, since the value of } \\
r_{c a l}>r_{c r i}=0.20 \text {, whereas } \\
6 \text { instruments are not valid } \\
\text { to use because the value of } \\
r_{c a l}<r_{c r i}=0.20 \text {. }\end{array}$ & $\begin{array}{l}22 \text { instruments are valid } \\
\text { to use, since the value } \\
\text { of } \quad r_{c a l}>r_{c r i}=0.20 \text {, } \\
\text { whereas } 6 \text { instruments } \\
\text { are not valid to use } \\
\text { because the value of } \\
r_{c a l}<r_{c r i}=0.20 \text {. }\end{array}$ & $\begin{array}{l}15 \text { instruments are valid to } \\
\text { use, since the value of } \\
r_{c a l}>r_{c r i}=0.20 \text {, whereas } \\
5 \text { instruments are not valid } \\
\text { to use because the value } \\
\text { of } r_{c a l}<r_{c r i}=0.20 \text {. }\end{array}$ \\
\hline \multicolumn{2}{|c|}{ Reliability } & $\begin{array}{l}\text { Based on the reliability } \\
\text { test, it found that } 14 \\
\text { instruments are reliable to } \\
\text { use since the value of } \\
a_{c a l}=0.78^{3} a_{c r i}=0.70 .\end{array}$ & $\begin{array}{l}\text { Based on the reliability } \\
\text { test, it found that } 22 \\
\text { instruments are reliable } \\
\text { to use since the value of } \\
a_{c a l}=0.84^{3} a_{c r i}=0.70 .\end{array}$ & $\begin{array}{l}\text { Based on the reliability } \\
\text { test, it found that } 15 \\
\text { instruments are reliable to } \\
\text { use since the value of } \\
a_{c a l}=0.70^{3} a_{c r i}=0.70 .\end{array}$ \\
\hline
\end{tabular}

\section{RESULTS AND ANALYSIS}

Based on the aim of this study is to find the influence of mathematical beliefs and thinking styles according to the mathematics communication, the Multiple Linier Regression were applying. It works 
with some assumption as follow.

\section{Residual has mean equal to zero}

Testing this assumption was done by SPSS, as shown in Figure 1, where the $\mathrm{x}$-axis and $\mathrm{y}$-axis represent the number of respondent and the value of residual, respectively. It shows that the residual was spread randomly around the zero value and the assumption was accepted.

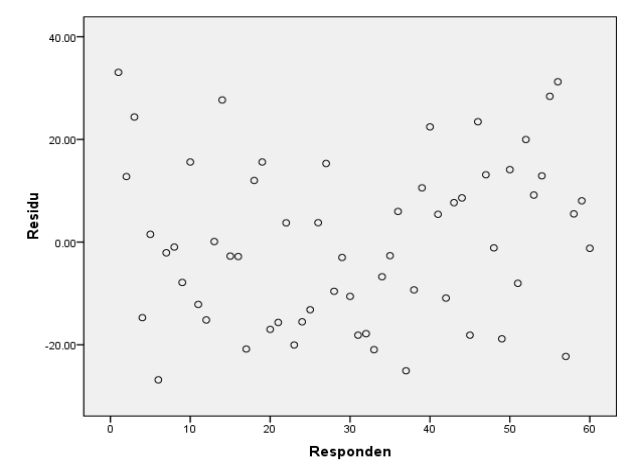

Figure 1. Testing the assumption of mean equal to zero

\section{Residual has constant variance (Homoscedasticity)}

Homoscedasticity assumption means that all the residuals have a constant variance, where the residuals approximately have the same distance from the mean line. Unstandardized residual graph is the common approach for testing the homoscedasticity assumption, as shown in Figure 2. The prediction value of dependence variable and the value of residual were represented as $\mathrm{x}$-axis and $\mathrm{y}$ axis, respectively.

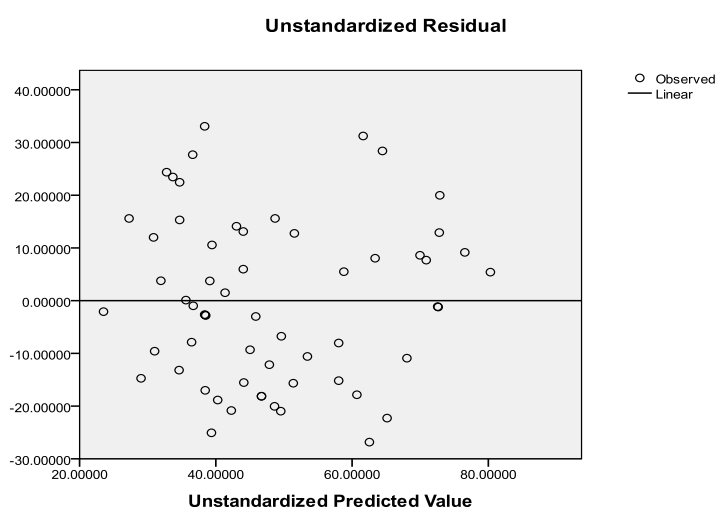

Figure 2. Unstandardized residual graph

\section{Residual are normally distributed}

The Kolmogorof-Smirnov (Liliefors) was used for testing normally assumption with level of significant is 0.05 , where

$$
\begin{aligned}
& H_{0}=\text { residual have normal distribution. } \\
& H_{1}=\text { residual does not have normal distribution. }
\end{aligned}
$$

The results from Kolmogorof-Smirnov was shown in Table 3, since the value of 
$\operatorname{Sig}_{\text {cal }}=0.200>\operatorname{Sig} g_{\text {cri }}=0.05$ then $H_{0}$ is accepted.

Table 3.

Preliminary Data Analysis

\begin{tabular}{|c|c|c|}
\hline \multicolumn{3}{|c|}{ Kolmogorof-Smirnov } \\
\hline $\begin{array}{l}\text { Stat } \\
\text { istic }\end{array}$ & $\mathrm{f}^{\mathrm{d}}$ & ig. $S$ \\
\hline $7^{.07}$ & $0^{6}$ & $00^{.2}$ \\
\hline
\end{tabular}

*this is a lower bound of the true significane

Aside of Kolmogorof-Smirnov, q-q plot also can be use for testing normality assumption, as shown in Figure 3. It shows that the residual have normal distribution.

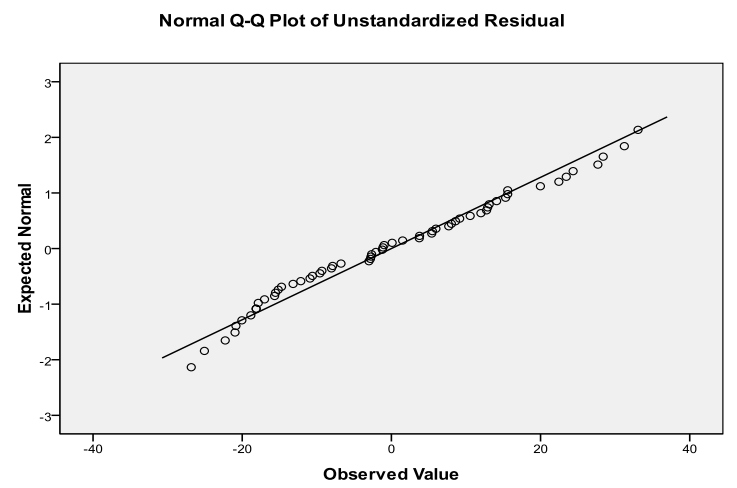

Figure 3. Q-Q plot for testing normality assumption

\section{Residual are mutually independent}

Durbin-Watson test was used for testing independency assumption between thinking styles $\left(X_{1}\right)$ and mathematical beliefs $\left(X_{2}\right)$, where

$H_{0}: r=0$ means there is no correlation between variable $X_{1}$ and $X_{2}$

$H_{1}: r>0$ for positive correlation or $r<0$ for negative correlation.

The criteria are, if $d_{c a l}<d_{u}$ then $H_{0}$ was rejected and if $d_{c a l}>d_{u}$ then accept $H_{0}$. The results of Durbin-Watson test was shown in Table 4, where the value of $d_{\text {cal }}=1.681$, it means there is no correlation between variable $X_{1}$ and $X_{2}$. Note that, the value of $d_{L}=1.514$ (lower critical value) $d_{u}=1.652$ (upper critical value) from the level of significant 0.05 and number of participants $n=60$. 


\section{Table 4.}

Durbin-Watson test

\begin{tabular}{|c|l|r|c|c|c|}
\hline Model & R & R Square & Adjusted R Square & $\begin{array}{l}\text { Std. Error of } \\
\text { the Estimate }\end{array}$ & Durbin-Watson \\
\hline 1 & $0.676^{*}$ & 0.457 & 0.438 & 15.889 & 1.681 \\
\hline
\end{tabular}

*Predictors: (Constant), Beliefs, Thinking styles

Based on the previous results, it shows that the condition of the data was satisfy all the assumption, then testing the hypothesis can be calculated. The results of applying Multiple Linier Regression in SPSS, is shown in Table 5. The value of F Significance is Sig $=0.000<0.05$ and the value of $F_{c a l}=23.966>F_{c r i}=3.16$, then $H_{0}$ is accepted. It means there is an influence of mathematical beliefs and thinking styles according to the mathematics communication. The value of R Square shows that there is 0.457 or $45.7 \%$ the influence of mathematical beliefs and thinking styles according to the mathematics communication. These results are consistent with Uygun and Kunt (2014) showing that there is a significant relationship between the thinking style and attitudes of prospective teachers toward their teaching profession which is reflected in their mathematical communication skills. Also, consistent with Mosvold and Fauskanger's research (2012) that highlights gaps about the need for belief in knowledge and study of mathematics.

\section{Table 5.}

Testing the Hypothesis.

\begin{tabular}{|l|l|l|l|l|l|l|}
\hline \multicolumn{7}{|c|}{ Model Summaryb } \\
\hline R & R Square & Adjusted R Square & \multicolumn{1}{l|}{ Std. Error of the Estimate } & \multicolumn{2}{l|}{ Durbin-Watson } \\
\hline $0.676 \mathrm{a}$ & 0.457 & 0.438 & 15.889 & 1.681 \\
\hline \multicolumn{7}{|c|}{ ANOVA } \\
\hline
\end{tabular}

Based on the Multiple Linier Regression form $Y=b_{0}+b_{1} X_{1}+b_{2} X_{2}+e$, we can make the new form of it according to the value in unstandardized coefficients as $Y=-104.589+3.751 X_{1}+0.918 X_{2}$. It means that the value of $Y$ is -104.589 with the assumption that the value of $X_{1}$ and $X_{2}$ are constant. 


\section{CONCLUSION}

The mathematical communication ability played an important role in providing prospective students. This is because mathematical communication is effective in improving students' achievement, conceptual understanding and reducing the anxiety about mathematics. However, learning mathematics these days still adopts the concept of teacher centered, where all the knowledge are given directly from teachers to students. The quality of the teacher is the most important factor in improving the quality of education in Indonesia. The study has been done before by some researchers and they found that thinking styles and mathematical beliefs have a significant impact on the performance of the teacher. This then lead us to find whether there is an influence between thinking styles and mathematical beliefs according to the mathematical communication. Based on the value of $\mathrm{R}$ Square applied in the SPSS showed that there is 0.457 or $45.7 \%$ the influence of mathematical beliefs and thinking styles according to the mathematics communication in students in Elementary Teacher Studies program in UPBJJ-UT Jakarta.

\section{REFERENCES}

Amsberg, J. (2010). Transforming Indonesia's Teaching Force. Vol.I Executive Summary. Jakarta: Public Disclosure Authorized

Arikunto, S. (2009). Dasar-dasar Evaluasi Pendidikan. Jakarta: Bumi Aksara.

Ayele, M.A. (2016). Mathematics Teachers' Perceptions on Enhancing Students' Creativity in Mathematics. IEJME-Mathematics Education, 11(10), 3521-3536.

Baroody, A.J. (1993). Fostering the Mathematical Learning of Young Children, in Handbook of Research on the Education of Young Children, ed: New York: Macmillan.

Braga, A. (2003). Journal Writing, An Alternative Method of Assessing Students' Achievement and Anxiety in High School Pre-Calculus. Unpublished Thesis. MPSC. Cagayan de Oro City, Philippines

Deborah. (2001). Teacher's Beliefs and Practices Related to Mathematics Instruction. Teaching and Teacher Journal Education, 17, 213-226.

De Bono, E. (1970). Lateral thinking, Creativity Step by Step. New York: Harper \& Row.

Department of Education Order No. 64, series 2013

Furinghetti, F and Pehkonen, E. (2000). A Comparative Study of Students' beliefs concerning Their Autonomy of Doing Mathematics, Nordisk Matematikkdidaktikk, 8(4), 7-26

Gardner, H. (1983). Frames of Mind: The Theory of Multiple Intelligences. New York: Basic Books.

Hair, J.F., Celsi, M.W., Money,A.H and Samuoel, P. (2011). Essentials of business methods, $2^{\text {nd }}$ ed. Armonk, New York: M.E. Sharpe Inc.

Kuinisala, T. (2005). Interactive Writing: Its Effects on Students' Achievement Scores in High School Mathematics. Unpublished Thesis. Mindanao Polytechnic State Colege de Oro City. 
Leder, G.C., Pehkonen, E and Torner, G. (2002). Beliefs: A Hidden Variable in Mathematics Education? Dordrecht: Kluwer Academic Publishers.

Lomibao, L.S., Luna, C.A and Namoco, R. A. (2016). The Influence of Mathematical Communication on Students' Mathematics Performance and Anxiety". American Journal of Education Research, 4(5), 378-382.

Mandler, G. (1989). Affect and learning: Causes and consequences of emotional interactions, in Affect and mathematical problem solving: A new perspective, ed: New York: Springer-Verlag.

Maier, H. (2000). Schreiben im Mathematikkunterricht”. Mathemtik Lehren.

McLeod, D.B. (1989). Beliefs, Attitudes, and Emotions: New Views of Affect in Mathematics Education", in Affect and Mathematical Problem Solving: A New Perspective, ed: New York: Springer-Verlag.

Mosvold, R and Fauskanger, J. (2012). Teacher's Beliefs about Mathematical Knowledge for Teaching Definitions. International Electronic Journal of Mathematics Education, Hamilton: University of Stavanger.

Naga, D.S. (2012). Teori Skor pada Pengukuran Mental. Jakarta: PT. Nagarani Citrayasa.

National Council of Teachers of Mathematics. (2000). Principles and standards for school mathematics. Reston, VA: National Council of Teachers of Mathematics Publishing

Rahman, R.A., Yisof, Y.M., Kashefi, H and Baharun, S. (2012). Developing mathematical communication skills of engineering students. Paper presented at Procedia-Sosial and Behavioral Sciences

Sharma, P and Neetu. (2011) A Study of Learning Thinking Style of Secondary School Students in Relations to Their Academic Achievment. International Journal on New Trends I Education and Their Implications.

Schoenfeld, A.H. (1990). A source book for college mathematics teaching. Committee on the Teaching of Undergraduate Mathematics of the Mathematical Association of America. USA.

Schoenfeld, A.H. (1992). Learning to Think Mathematically: Problem Solving, Metacognition, and Sense Making in Mathematics, in Handbook of Research on Mathematics Teaching and Learning, ed: New York: Macmillan.

Sünbül, A.M. (2004). Düşünme stilleri ölçeğinin geçerlik ve güvenirliği. Eğitim ve Bilim Dergisi, $132,25-42$.

Thompson, A.G. (1992). Teachers'Beliefs and Conceptions: A Synthesis of the Research, in Handbook of Research on Mathematics Teaching and Learning, ed: New York: Macmillan.

Uygun, M and Kunt, H. (2016). An Analysis of the Relationship Between Prospective Teachers' Thinking Styles and Their Attitudes to Teaching Profession According to Various Variables. International Electronic Journal of Elementary Education, 6(2), 357-370. 
Zabukovec, Z and Kobal-Grum, D. (2004). Relationship between students thinking styles andsocial skills. Psychology Science, 46, 156-166. 